\title{
KAJIAN PERTUMBUHAN DAN HASIL PADI DI AREAL PERSAWAHAN DEKAT PERTANAMAN BUNGA KAMBOJA (SEBAGAI REFUGIA) DI DESA JATEN KECAMATAN JATEN KABUPATEN KARANGANYAR
}

\author{
Tri Rahayu') dan Shalahuddin Mukti Prabowo') \\ 1)Fakultas Teknik, Sains dan Pertanian, Program Studi Agroteknologi, Universitas Islam Batik Surakarta, JI \\ KH Agus Salim No 10 Surakarta, Telp (0271) 714751, email: trirahayuharyomo@gmail.com
}

\begin{abstract}
Abstrak
Hama utama yang menyerang tanaman padi diantaranya adalah wereng coklat dan penggerek batang padi. Rata-rata kehilangan hasil produksi pertanian karena serangan OPT $\pm 30 \%$ dari potensi hasil, dan kehilangan hasil karena hama sekitar $20-25 \%$. Penggunaan pestisida secara intensif memang dapat meningkatkan produksi sawah cukup tinggi, namun dampak negatif yang ditimbulkan dapat menyebabkan ketidakseimbangan rantai sistem di lahan pertanian yang menyebabkan populasi hama meningkat. Salah satu cara yang dapat digunakan untuk mempertahankan keanekaragaman hayati karena dampak negatif penggunaan bahan kimia yaitu dengan cara memanfaatkan tumbuhan berbunga (refugia) yang pada pematang sawah. Hasil penelitian dan pengamatan dengan net penangkap serangga, di lahan terdapat 8 jenis hama, Serangga parasid ada 3 jenis Dan predator yang tertangkap ada 7 jenis. Hasil analisis regresi untuk peubah tinggi tanaman, Berat brangkasan basah, Berat brangkasan kering, Jumlah anakan produktif, dan Berat gabah kering per petak berpola cubic. Refugia efektif dari jarak $10 \mathrm{~m}$ sampai $40 \mathrm{~m}$. Setelah jarak $40 \mathrm{~m}$ akan menurun hingga batas minimum pada jarak $80 \mathrm{~m}$. Demikian juga pada peubah pertumbuhan dan hasil tanaman (tinggi tanaman, berat brangkaan basah per rumpun, berat brangkasan kering per rumpun, berat gabah kering per rumpun, berat gabah kering per petak dan berat 1000 butir gabah) tinggi pada jaran $40 \mathrm{~m}$ dari refugia dan menurun hingga terendah pada jarak $80 \mathrm{~m}$ dari refugia.
\end{abstract}

Kata kunci: Padi, Pertumbuhan dan hasil padi , Refugia bunga kamboja,

\section{Abstract}

The main pests that attack rice plants include the brown planthopper and rice stem borer. The average loss of agricultural production due to pest attack is $\pm 30 \%$ of potential yield, and loss of yield due to pests is around $20-25 \%$. Intensive use of pesticides can indeed increase rice field production quite high, but the negative impact it causes can cause an imbalance in the chain system in agricultural land which causes the pest population to increase. One of the ways that can be used to maintain biodiversity due to the negative impact of using chemicals is by utilizing flowering plants on rice fields. The results of research and observations with net insect catchers, in the land there are 8 types of pests, 3 types of parasid insects and 7 types of predators that were caught. Regression analysis results for the variables of plant height, wet stover weight, dry stover weight, number of productive tillers, and dry grain weight per plot with cubic pattern. Effective refugia from a distance of $10 \mathrm{~m}$ to $40 \mathrm{~m}$. After a distance of $40 \mathrm{~m}$ it will decrease to a minimum at a distance of $80 \mathrm{~m}$. Likewise, the growth and yield variables (plant height, wet scarcity weight per clump, dry stover weight per hill, dry grain weight per hill, dry grain weight per plot and weight 1000 grains of grain) were high at a distance of $40 \mathrm{~m}$ from refugia and decreased. to the lowest at a distance of $80 \mathrm{~m}$ from the refugia..

Keywords: Rice, Frangipani flower Refugia, rice growth and yield

\section{PENDAHULUAN}

Tanaman padi merupakan salah satu tanaman pangan utama di Indonesia. Untuk meningkatkan produksi padi, pada tahun tujuh puluhanan pemerintah mencanangkan program yang dikenal dengan Revolusi Hijau. Dengan program ini, mulai digunakan varietas unggul, pupuk, pestisida kimia, dan saluran irigasi. Cara budidaya ini dikenal dengan pertanian konvensional. Cara budidaya konvensional di satu sisi terbukti mampu meningkatkan produksi pangan nasional, tetapi disisi lain disinyalir telah menurunkan produktivitas lahan pertanian terutama di daerah-daerah sentra produksi (Kartini, 2001) dan menimbulkan permasalahan lingkungan sebagai dampak 
dari penggunaan pupuk dan pestisida kimia yang terus menerus dan tidak terkendali (Irvany, 2011).

Tanaman padi merupakan tanaman pangan utama di Indonesia. Pertambahan penduduk di Indonesia semakin meningkat, sehingga kebutuhan bahan pangan juga akan meningkat. Namun tidak sesuai dengan ketersediaan bahan pangan. Ketersediaan bahan pangan yang tidak sesuai dikarenakan cara budidaya petani yang kurang tepat, sehingga berdampak pada penurunan hasil produksi. Dalam upaya peningkatan produktivitas padi, masih terdapat kendala diantaranya adalah adanya serangan hama. Hama utama yang menyerang tanaman padi diantaranya adalah wereng coklat dan penggerek batang padi. Beberapa hama lainnya yang berpotensi merusak pertanaman padi adalah wereng punggung putih, wereng hijau, lembing batu, ulat grayak, pelipat daun, dan walang sangit (Effendi, 2009). Rata-rata kehilangan hasil produksi pertanian karena serangan OPT $\pm 30 \%$ dari potensi hasil, dan kehilangan hasil karena hama sekitar 20-25\% (Untung, 2010).

Populasi hama wereng dalam jumlah yang cukup tinggi dapat menyebabkan tanaman padi mengalami kekeringan atau sering disebut dengan hopperburn yaitu tanaman padi menjadi kering kuning kemerahan seperti terbakar. Pada periode tahun 2000-2005, luas areal pertanaman padi yang terserang hama wereng coklat mencapai 20.000 ha per tahun (Kartohardjono 2011).

Penggunaan pestisida secara intensif memang dapat meningkatkan produksi

Penelitian dilakukan dengan metode petak contoh (ubinan) di areal persawahan desa Jaten, Kecamatan Jaten Kabupaten Karanganyar pada bulan Agustus 2019. Bahan yang digunakan meliputi pertanaman padi mulai dari pembibitan, masa vegetative, masa bunting (generative) dan panen.Alat yang digunakan untuk meliputi alat-alat panen, alat pengemasan dan lahan sawah cukup tinggi, namun dampak negatif yang ditimbulkan dapat menyebabkan ketidak seimbangan rantai sistem di lahan pertanian yang menyebabkan populasi hama meningkat. Hal ini seperti yang telah disampaikan oleh (Muhibah dan Leksono, 2015),bahwa jika penggunaan pestisida sintetik yang digunakan berlebihan dapat merusak keseimbangan ekosistem, karena jika aplikasi pestisida yang digunakan tidak selektif akan mengakibatkan populasi hama meningkat namun populasi musuh alami yang mampu mengendalikan populasi hama berkurang.

Salah satu cara yang dapat digunakan untuk mempertahankan keanekaragaman hayati karena dampak negatif penggunaan bahan kimia yaitu dengan cara memanfaatkan tumbuhan berbunga (refugia) yang pada pematang sawah. Refugia merupakan suatu area yang ditumbuhi beberapa jenis tumbuhan yang dapat menyediakan tempat perlindungan, sumber pakan atau sumberdaya yang lain bagi musuh alami seperti predator dan parasitoid (Nentwig, 1998).

Sehingga keberadaan musuh alami ini harus dipertahankan dalam upaya pencegahan peledakan hama, salah satunya dengan penanaman tumbuhan berbunga di sekeliling pematang areal pertanaman padi. Akibat penggunaan pestisida sintetik yang kurang bijaksana maka akan menimbulkan terjadinya peledakan hama yang dapat merugikan petani karena berpengaruh terhadap hasil panen karena musuh alami berkurang (Weni et al., 2016).

\section{BAHAN DAN METODE}

penjemuran. Petak contoh (ubinan) yang dipakai pada penelitian ini yaitu berada di sekitar sumber tanaman refugia. Kedudukan populasi pertanaman padi dibedakan ke dalam 8 kelompok berdasarkan jarak dari sumber tanaman refugia, yaitu: $0 \mathrm{~m}, 10 \mathrm{~m}, 20$ $\mathrm{m}, 30 \mathrm{~m}, 40 \mathrm{~m}, 50 \mathrm{~m}, 60 \mathrm{~m}, 70 \mathrm{~m}$ dan 80 m. Tanaman contoh diambil secara acak pada tiap-tiap kelompok, masing-masing sebanyak 
Agrisaintifika

Jurnal Ilmu-Ilmu Pertanian

Vol. 5, No. 1, 2021

Rahayu, et al. 2021

3 petak. Ukuran petak tanaman contoh (ubinan) $1 \mathrm{~m} \times 1 \mathrm{~m}$. Pada sumber pertanaman refugia maupun tiap-tiap petak tanaman contoh dilakukan pengamatan serangga menggunakan jaring, meliputi jenis dan populasi serangga. Pada petak tanaman contoh pengamatan dilakukan pada masa vegetatif, generatif, dan panen. Panen dilakukan pada saat tanaman berumur 90 hari atau saat telah memenuhi kriteria panen, yaitu: setelah bulir padi keras, berwarna hitam dan daun bendera masih hijau atau mulai menguning.

Analisis data dilakukan menggunakan analisis regresi. Jarak pertanaman padi dari sumber tanaman refugia sebagai variabel bebas (independent variable) sedangkan tiaptiap variabel pengamatan tanaman sebagai variabel tergantung (dependent variable). Variabel pengamat-an meliputi tinggi tanaman, berat brangkasan segar, berat brangkasan kering jumlah malai, berat gabah kering per rumpun, berat gabah kering per petak contoh, berat 1000 butir gabah.

\section{HASIL DAN PEMBAHASAN}

\section{Jenis hama, parasitoid dan predator}

Hasil pengamatan pada tanaman kamboja menunjukkan bahwa, tidak ditemukan hama padi pada area pertanaman kamboja. Pengamatan pagi siang dan sore ditemukan 3 jenis parasit ( Telenomus remus, Tetrastichus schoenobii Ferr dan Trichogramma japonicum) dan 3 jenis predator (Oxyopes sp., Coccinelade sp. Dan Phidipus $s p$ ). Sedangkan pada lahan padi pada jarak $10 \mathrm{~m}$ sampai dengan $80 \mathrm{~m}$ terdapat 8 jenis hama yaitu Tahya orizyfora, Cnaphalocrocis medinalis, Hydrellia philippina, Nilaparvata lugens, Nephotettix spp, Sogatella furcifera, Leptocorisa acuta, Locusta migratoria manilensis Meyen. Serangga parasid ada 3 jenis yaitu Telenomus remus, Tetrastichus schoenobii Ferr, Trichogramma japonicum. Dan predator yang tertangkap ada 7 jenis yaitu Mantis religiosa $L$, Menochilus sexmaculatus L, Phidippus sp, Oxyopes javanus Thorell, Scipinia horrid, Paederus littoralis, Atractomorpha sp. Nama-nama dan jumlah hama, parasitoid dan predator tertera pada Lampiran 1.

Jumlah jenis hama, parasitoid dan predator yang ada berdasarkan jarak antara bunga kamboja dengan lahan, tertera pada Tabel 2. Hasil penelitian sejalan dengan yang dilakukan oleh Pujiastuti et al. (2015), yang menyatakan bahwa penggunaan tanaman refugia berupa tanaman kacang panjang dan jagung pada plot tanaman padi pasang surut menunjukkan kelimpahan jumlah serangga herbivora yang di dapat pada subplot dengan tanaman refugia lebih rendah dibandingkan dengan tanaman padi yang tanpa refugia, baik pada vase vegetatif dan generatif.

Beberapa penelitian menyebutkan jenis tanaman hias yang berpotensi sebagai refugia antara lain bunga matahari (Helianthus annuus), bunga kertas zinnia (Zinnia peruviana), (Zinnia acerosa), (Zinnia bicolor), (Zinnia grandiflora), (Zinnia elegans), kenikir (Cosmos caudatus) dll.(Allifah et.al 2013). Tumbuhan liar merupakan mikrohabitat bagi kelangsungan hidup suatu organisme tertentu. Dalam ekosistem pertanian, mikrohabitat buatan yang baik adalah jika dibuat pada tepian atau di dalam lahan pertanian (Frei dan Manhart 1992). Dadi (2010) melaporkan bahwa keanekaragaman jenis gulma berpengaruh terhadap kemelimpahan Arthropoda di ekosistem sawah. Kombinasi tumbuhan famili Asteraceae.

\section{Hasil pengamatan pada peubah}

Hasil pengamatan pada peubah yang diamati tercantum pada Tabel 3.

a. Tinggi tanaman

Grafik 1 menunjukkan analisis model regresi berbeda nyata untuk peubah tinggi tanaman dengan pola cubic. Tinggi tanaman tertinggi dicapai pada jarak $30 \mathrm{~m}-40 \mathrm{~m}$ dari bunga kamboja kemudian tinggi tanaman akan menurun sejalan dengan tambahnya jarak dengan refugia. Tinggi tanaman terendah dicapai pada jarak $90 \mathrm{~m}$. Berikutnya tinggi tanaman akan kembali naik pada jarak 100 m. Grafik tertera pada Grafik 1. Hal ini 
terjadi mungkin disebabkan kondisi lahan setelah $100 \mathrm{~m}$, yang peneliti tidak dapat mengendalikan kondisinya, apakah disemprot dengan pestisida atau tidak.

b. Jumlah anakan produktif

Grafik 2 menunjukkan analisis regresi pada paubah jumlah anakan produktif yang berpola cubic. Jumlah anakan produktif tertinggi dicapai pada jarak $40 \mathrm{~m}$ dari bunga kamboja. Grafik tertera pada Grafik 2. Jumlah anakan produktif terendah dicapai pada jarak $80 \mathrm{~m}$. Berikutnya Jumlah anakan produktif akan kembali naik pada jarak 90 m -100 m. Grafik tertera pada Grafik 2. Hal ini terjadi mungkin disebabkan kondisi lahan setelah $100 \mathrm{~m}$, yang peneliti tidak dapat mengendalikan kondisinya, apakah disemprot dengan pestisida atau tidak.

c. Berat Brangkasan basah per Rumpun

Grafik 3 menunjukkan analisis regresi pada peubah berat brangkasan basah per rumpun model regresi yang berpola cubic. Berat Brangkasan basah per Rumpun tertinggi dicapai pada jarak $40 \mathrm{~m}$ dari bunga kamboja. Grafik tertera pada Grafik 3

Berat Brangkasan basah per Rumpun terendah dicapai pada jarak $80 \mathrm{~m}$. Berikutnya Jumlah anakan produktif akan kembali naik pada jarak 90 m-100 m. Grafik tertera pada Grafik3. Hal ini terjadi mungkin disebabkan kondisi lahan setelah $100 \mathrm{~m}$, yang peneliti tidak dapat mengendalikan kondisinya, apakah disemprot dengan pestisida atau tidak.

d. Berat brangkasan kering per rumpun

Grafik 4 menunjukkan analisis regresi padapada paubahberat brangkasan kering per rumpun model regresi yang berpola cubic. Berat Brangkasan kering per Rumpun tertinggi dicapai pada jarak $40 \mathrm{~m}$ dari bunga kamboja. Grafik tertera pada Grafik 4. Berat Brangkasan kering per Rumpun terendah dicapai pada jarak $80 \mathrm{~m}$. Berikutnya Berat Brangkasan Kering per Rumpun akan kembali naik pada jarak $90 \mathrm{~m}-100 \mathrm{~m}$. Grafik tertera pada Grafik 4. Hal ini terjadi mungkin disebabkan kondisi lahan setelah $100 \mathrm{~m}$, yang peneliti tidak dapat mengendalikan kondisinya, apakah disemprot dengan pestisida atau tidak.

e. Berat Gabah Kering Panen per Petak

Grafik 5. Hubungan antara berat brangkasan kering per rumpun dengan jarak analisis regresi padapada paubah berat gabah kering per petak model regresi yang berpola cubic. Berat Brangkasan kering per Rumpun tertinggi dicapai pada jarak $40 \mathrm{~m}$ dari bunga kamboja. Grafik tertera pada Grafik 5. Berat gabah kering per petak terendah dicapai pada jarak $80 \mathrm{~m}$. Berikutnya Berat gabah kering per petak akan kembali naik pada jarak $90 \mathrm{~m}-100 \mathrm{~m}$. Grafik tertera pada Grafik 5. Hal ini terjadi mungkin disebabkan kondisi lahan setelah $100 \mathrm{~m}$, yang peneliti tidak dapat mengendalikan kondisinya, apakah disemprot dengan pestisida

f. Berat Gabah kering per Rumpun

Dari analisis regresi pada peubah Berat gabag kering per rumpun model regresi tidak berbeda nyata

g. Berat 1000 butir gabah

Seperti pada peubah-peubah sebelumnya , pola hubungan pada peubah berat 1000 butir gabah menunjukkan pola cubic, grafik tertera pada Grafil 6.

Pertumbuhan dan hasil tanaman padi ternyata dipengaruhi oleh adanya refugia tanaman kamboja ini. Hal ini tercermin dari peubah-peubah Tinggi tanaman, Jumlah anakan produktif, Berat Brangkasan basah per Rumpun, Berat brangkasan kering per rumpun, Berat Gabah Kering Panen per Petak, Berat Gabah kering per Rumpun, Berat 1000 butir gabah menunjukkan hasil yang sama. Masing-masing peubah menunjukkan angka tertinggi pada jarak $40 \mathrm{~m}$ dan menurun sampai hasil terendah pada jarak $80 \mathrm{~m}$.

\section{SIMPULAN}

a. Banyak parasitoid dan predator yang berada pada dekat refugia kamboja dan tidak ditemukan hama padi .

b. Kehadiran hama, parasitoid dan predator mulai mulai ada pada jarak 10 $\mathrm{m}$ dan terjadi puncaknya pada jarak 40 
$m$ dan berkurang sampai pada jarak 80 $\mathrm{m}$ dari refugia.

c. Regresi pola cubic terjadi pada peubah tinggi tanaman, jumlah anakan produktif, berat brangkasan basah per rumpun, berat brangkasan kering per rumpun, gabah kering per petak, dan berat 1000 butir gabah,

d. Pada peubah berat gabah kering per rumpun , regresinya tidak berbeda nyata.

e. Refugia bunga kamboja efektif pada jarak 10-40 m berkurang hingga kurang efektif jarak $80 \mathrm{~m}$.

f. Kehadiran bunga kamboja layak dipertimbangkan sebagai refugia.

\section{DAFTAR PUSTAKA}

Allifah AF.AN.; Bagyo Yanuwiadi; Zulfaidah Panata Gama; Amin Setyo Laksono.Refugia sebagai microhabitat untuk meningkatkan peran musuh alami di lahan pertanian.Prosiding FMIPA Universitas Pattimura 2013.ISBN : 978-602-97522-0-5. Jurusan Biologi. Fakultas MIPA. Universitas Brawijaya Malang

Dadi, 2010. Potensi Agroforestri Pendukung Eksistensi Arthropoda Predator Wereng Padi diEkosistem Sawah. Disertasi. Program Studi IImu-IImu Pertanian. Program PascaSarjana Fakultas Pertanian. Universitas Brawijaya Malang.

Effendi, BS. 2009. Strategi pengendalian hama terpadu tanaman padi dalam perspektif praktek pertanian yang baik (Good Agricultural Practices). Jurnal Pengembangan Inovasi. 2(1): 65-78.

Frei, G., and Manhart, C. 1992. Nutzlinge und Schadlinge an kunstlich angelegtenAckerkrauststreifen in Getreidefeldern. Agrarokologie 4:1140.

Irvany, PN. 2011. Penerapan teknologi pertanian padi organic di kampung Ciburuy, Desa Ciburuy, Kecamatan
Cigombong, Kabupaten Bogor. [Skripsi]. Fakultas Ekologi Manusia. Institut Pertanian Bogor.

Kalshoven, L. G. E., (1981). The Pest of Crops in Indonesia. Revised andTranslated By P.A. Van der laan. Jakarta: PT. Ichtiar Baru-Van Hoeve

Kartini, N.L. 2001. Strategi meningkatkan dan melestarikan kesuburan tanah berkelanjutan.Ceramah Agroindustri dan Agribisnis. Dinas Koperasi Bali. 15 Agustus 2001.14 halaman.

Kartohardjono, Arifin. 2011. Penggunaan Musuh Alami Sebagai Komponen Pengendalian Hama Padi Berbasis Ekologi. Jurnal Pengembangan Inovasi Pertanian, 4(1): 29-46

Kurniawati N. dan Edhi M. 2015."Peran Tumbuhan Berbunga sebagai Media Konservasi Artropoda Musuh Alami". Jurnal Perlindungan Tanaman Indonesia, Vol. 19, No. 2, 2015: 5359

Las, I., K. Subagyono, \& A.P. Setiyanto. 2006. Isu dan pengelolaan lingkungan dalam revitalisasi pertanian. Indonesia Agricultural Research and Development Journal. Vol. 25(3):173193.

Letourneaua, D. and Miguel, A. 2003. Vegetation management and biological control inagroecosystems. Journal of Biological Control. University of California, Berkeley,Albany CA94706, USA.

Muhibah, T. I., \& Leksono, A. S. (2015). Ketertarikan Arthropoda Terhadap Blok Refugia (Ageratum Conyzoides I., Capsicum Frutescens I., dan Tagetes Erecta I.) Dengan Aplikasi Pupuk Organik Cair dan Biopestisida di Perkebunan Apel Desa Poncokusumo. Jurnal Biotropika, 3(3), 123-127.

Nentwig, 1998. Weedy Plant Species and Their Benefecial Arthropods: Potential forManipulation in Field Crops. In. C.H Pickett and R.L Bugg (ed) Enhancing BiologicalControl, Habitat Management to Promote Natural Enemies of Agricultural Pest.University of California Press. 
Agrisaintifika

Berkeley. Los Angles. London. 49 71.

Pujiastuti Y, H.W.S.Weni, Abu U. 2015. "Peran Tanaman Refugia terhadap Kelimpahan Serangga Herbivora pada Tanaman Padi Pasang Surut". Prosiding Seminar Nasional Lahan Suboptimal (8-9 Oktober 2015)

Pusat Penelitian dan Pengembangan Tanaman Pangan. 2010. Masalah lapang hamd, penyakit, hara pada padi. Kerja sama Balitpa, BP2TP, BPTP Sumut, BPTP Jabar, BPTP Jateng, BPTP DIY, BPTP Jatim, BPTP NTB, BPTP Sulsel, BPTP Kalsel, BPTP Kaltim dan IRRI.

Sinar Tani. 2016. "Refugia bukan sekedar penghias sawah". Sinar Tani Edisi 12-18 Oktober 2016. No. 3674. Tahun XLVII

Sitompul, M dan B.Guritno. 1995. Analisis pertumbuhan tanaman. Gadjah Mada Press.Yogyakarta.

Solichah, I.W. 2001. Uji Preferensi Serangga Syrpidhae Terhadap Beberapa
TumbuhanFamili Mimosaceae. Skripsi. Jurusan Biologi Fakultas MIPA Biologi. UNISMA.Malang.

Tjitrosoepomo, Gembong. 2013. Morfologi Tumbuhan. Yogyakarta. Gajah Mada University press

Untung K. 2010. Diktat Dasar-dasar IImu Hama Tanaman. Universitas Gajah Mada, Yogyakarta.

Wahyuni R, Wijayanti R, Supriyadi. 2013. "Peningkatan keragaman tumbuhan berbunga sebagai daya tarik predator hama padi". Journal of Agronomy Research2(5): 40-46

Wangiyana, Wayan, Z.Laiwan dan Sanisah. 2009. Pertumbuhan Dan Hasil Tanaman Padi Var.Ciherang Dengan Teknik Budidaya "SRI (System Of Rice Intensification)" Pada Berbagai Umur Dan Jumlah Bibit Per Lubang Tanam. Crop Agro (2): 1.

Weni, H. W. S., Pujiastuti, Y., \& Umayah, A. (2016).Efek Refugia terhadap Arthropoda Tanaman Padi (Oryza sativa) di Sawah Pasang Surut.In Prosiding Seminar Lahan Suboptimal (pp. 638-647). 
Agrisaintifika

Jurnal Ilmu-Ilmu Pertanian

Vol. 5, No. 1, 2021

Rahayu, et al. 2021

\section{Lampiran}

Tabel 2. Jumlah jenis hama, parasitoid dan predator sesuai jarak $(0 \mathrm{~m}-80 \mathrm{~m})$

\begin{tabular}{|c|c|c|c|c|c|c|c|c|c|c|c|c|c|c|c|c|c|c|c|c|c|c|c|c|c|}
\hline & & \multicolumn{24}{|c|}{ JUMLAH JENIS HAMA PARASITOID DAN PREDATOR PADA JARAK (m) } \\
\hline & 0 & & 10 & & & 20 & & & 30 & & & 40 & & & 50 & & & 60 & & & 70 & & & 80 & \\
\hline Jar & 0 & 7 & 8 & 6 & 4 & 5 & 3 & 3 & 4 & 2 & 5 & 5 & 3 & 6 & 7 & 5 & 2 & 3 & 3 & 4 & 4 & 2 & 3 & 3 & \\
\hline Para & 3 & 2 & 3 & 3 & 3 & 3 & 3 & 1 & 1 & 1 & 1 & 1 & 1 & 1 & 1 & 1 & 2 & 2 & 2 & 1 & 1 & 1 & 0 & 0 & \\
\hline Predator & 3 & 1 & 2 & 3 & 3 & 3 & 3 & 0 & 0 & 0 & 3 & 3 & 3 & 1 & 1 & 1 & 0 & & 0 & 1 & 1 & 1 & 0 & 0 & \\
\hline
\end{tabular}

Tabel 3. Rerata peubah yang diamati pada jarak $10 \mathrm{~m}-80 \mathrm{~m}$

\begin{tabular}{|c|r|r|r|r|r|r|r|}
\hline Rerata pada jarak & $\begin{array}{c}\text { TINGGI } \\
\text { TAN }\end{array}$ & JMR & BBBR & BBKR & GKP & GKR & $\begin{array}{c}\text { BERAT } \\
1000\end{array}$ \\
\hline I $(10 \mathrm{~m})$ & 100.33 & 4.08 & 107.60 & 44.40 & 645.67 & 41.73 & 24.40 \\
\hline II $(20 \mathrm{~m})$ & 101.93 & 4.20 & 127.27 & 52.33 & 540.33 & 44.60 & 24.47 \\
\hline III $(30 \mathrm{~m})$ & 100.80 & 3.99 & 127.80 & 50.93 & 620.00 & 42.93 & 23.83 \\
\hline IV $(40 \mathrm{~m})$ & 101.73 & 4.04 & 137.27 & 58.40 & 591.67 & 41.73 & 25.17 \\
\hline V $(50 \mathrm{~m})$ & 96.47 & 3.55 & 104.27 & 45.13 & 609.33 & 36.20 & 24.40 \\
\hline VI $(60 \mathrm{~m})$ & 96.20 & 3.64 & 98.27 & 45.80 & 614.33 & 36.53 & 25.73 \\
\hline VII $(70 \mathrm{~m})$ & 94.60 & 3.35 & 92.67 & 44.47 & 559.00 & 37.53 & 25.47 \\
\hline VIII $(80 \mathrm{~m})$ & 93.60 & 3.36 & 81.60 & 40.00 & 571.33 & 40.67 & 25.83 \\
\hline
\end{tabular}

$\begin{array}{ll}\text { Keterangan: } & \text { TT }: \text { Tinggi tanaman } \\ \text { JM } & : \text { Jumlah malai per rumpun } \\ \text { BBBP } & : \text { Berat Brangkasan Basah per Petak } \\ \text { BBKR : Berat Brangkasan Kering per Rumpun } \\ \text { GKP }: \text { Gabah kering panen per petak } \\ \text { GKR : Gabah Kering Panen per Rumpun } \\ \text { B1000 : Berat } 1000 \text { butir gabah }\end{array}$

Tabel 6. Model Summary and Parameter Estimates

Dependent Variable: TT

\begin{tabular}{|c|c|c|c|c|c|c|c|c|c|}
\hline \multirow{2}{*}{$\begin{array}{l}\text { Equa } \\
\text { tion }\end{array}$} & \multicolumn{5}{|c|}{ Model Summary } & \multicolumn{4}{|c|}{ Parameter Estimates } \\
\hline & $\begin{array}{c}\mathrm{R} \\
\text { Square }\end{array}$ & $\mathrm{F}$ & df1 & df2 & Sig. & $\begin{array}{c}\text { Constan } \\
t\end{array}$ & b1 & b2 & b3 \\
\hline $\begin{array}{l}\text { Cubi } \\
\text { c }\end{array}$ & 452 & 7,144 & 3 & 26 & 001 & 96,382 & 5,501 & $-1,604$ & 112 \\
\hline
\end{tabular}

The independent variable is JARAK. 
Agrisaintifika

Jurnal Ilmu-Ilmu Pertanian

Vol. 5, No. 1, 2021

Rahayu, et al. 2021

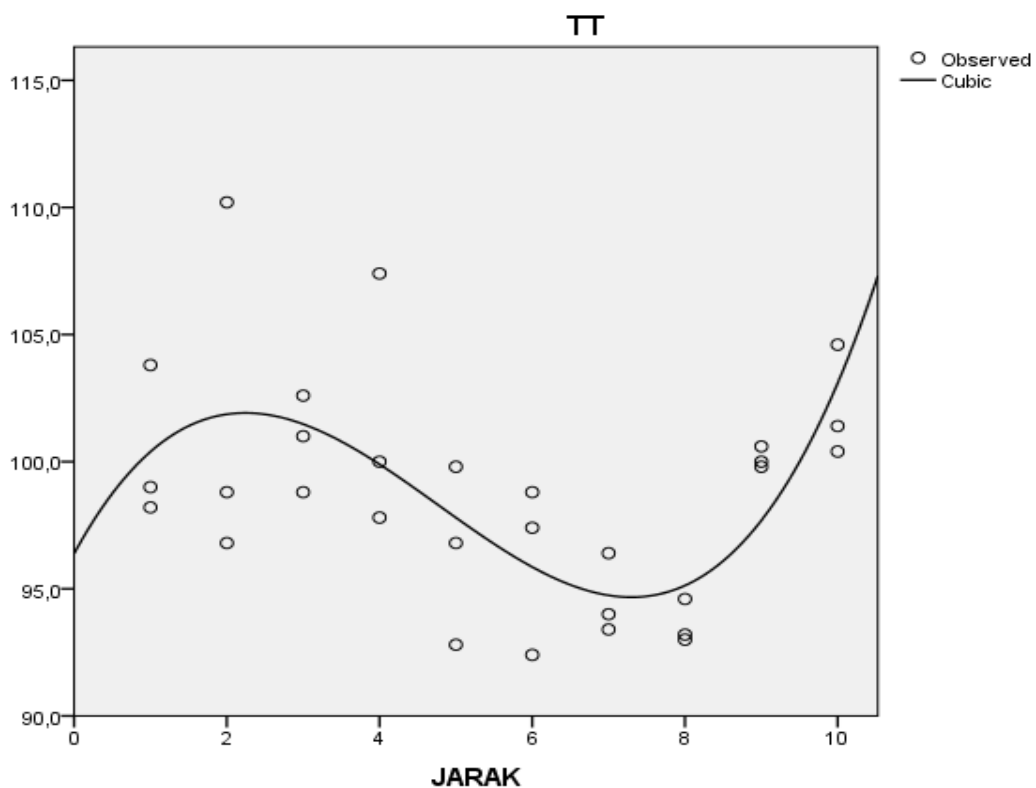

Grafik 1. Hubungan antara tinggi tanaman dan jarak

Tabel 7, Model Summary and Parameter Estimates

Dependent Variable: JM

\begin{tabular}{|l|r|r|r|r|r|r|r|r|r|}
\hline \multirow{2}{*}{$\begin{array}{l}\text { Equa } \\
\text { tion }\end{array}$} & \multicolumn{4}{|c|}{ Model Summary } & \multicolumn{4}{|c|}{ Parameter Estimates } \\
\cline { 2 - 10 } & $\begin{array}{c}\mathrm{R} \\
\text { Square }\end{array}$ & $\mathrm{F}$ & $\mathrm{df1}$ & $\mathrm{df2}$ & Sig. & Constant & b1 & b2 & b3 \\
\hline $\begin{array}{l}\text { Cubi } \\
\mathrm{C}\end{array}$ &, 518 & 9,311 & 3 & 26 &, 000 & 3,799 &, 410 &,- 133 &, 009 \\
\hline
\end{tabular}

The independent variable is JARAK.

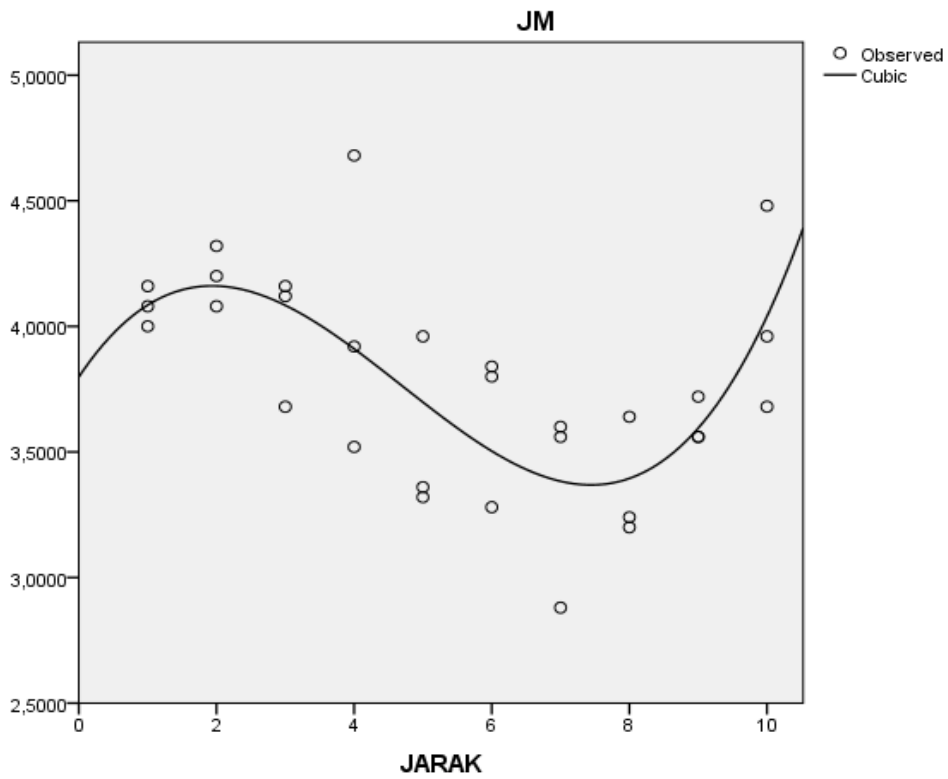

Grafik 2. Hubungan antara jumlah anakan Produktif dengan jarak 
Agrisaintifika

Jurnal Ilmu-Ilmu Pertanian Vol. 5, No. 1, 2021

Rahayu, et al. 2021

Dependent Variable: BBBP

\begin{tabular}{|l|r|c|c|r|r|r|r|r|r|}
\hline \multirow{2}{*}{$\begin{array}{l}\text { Equati } \\
\text { on }\end{array}$} & \multicolumn{5}{|c|}{ Model Summary } & \multicolumn{4}{|c|}{ Parameter Estimates } \\
\cline { 2 - 10 } & R Square & F & df1 & df2 & Sig. & Constant & b1 & b3 \\
\hline Cubic &, 523 & 9,521 & 3 & 26 &, 000 & 68,198 & 50,540 & 11,982 &, 738 \\
\hline
\end{tabular}

The independent variable is JARAK.

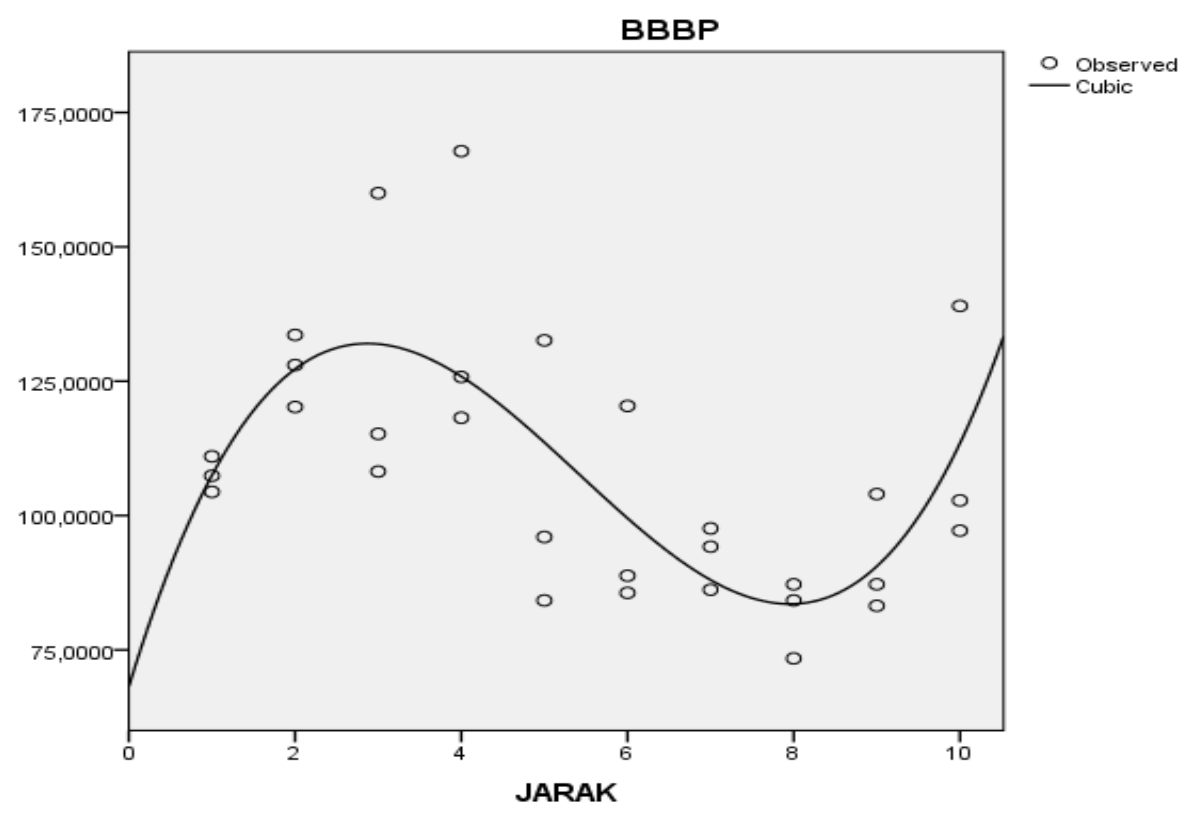

Grafik 3. Hubungan antara berat brangkasan basah per rumpun dengan jarak

Tabel 9, Model Summary and Parameter Estimates

Dependent Variable: BBKR

\begin{tabular}{|l|r|c|r|r|r|r|r|r|r|}
\hline \multirow{2}{*}{ Equation } & \multicolumn{4}{|c|}{ Model Summary } & \multicolumn{4}{|c|}{ Parameter Estimates } \\
\cline { 2 - 10 } & $\begin{array}{c}\mathrm{R} \\
\text { Square }\end{array}$ & $\mathrm{F}$ & $\mathrm{df1}$ & $\mathrm{df2}$ & Sig. & Constant & b1 & b2 & b3 \\
\hline Cubic &, 383 & 5,374 & 3 & 26 &, 005 & 29,942 & $\begin{array}{r}18,08 \\
4\end{array}$ & $-4,072$ &, 248 \\
\hline
\end{tabular}

The independent variable is JARAK. 
Agrisaintifika

Jurnal Ilmu-Ilmu Pertanian

Vol. 5, No. 1, 2021

Rahayu, et al. 2021

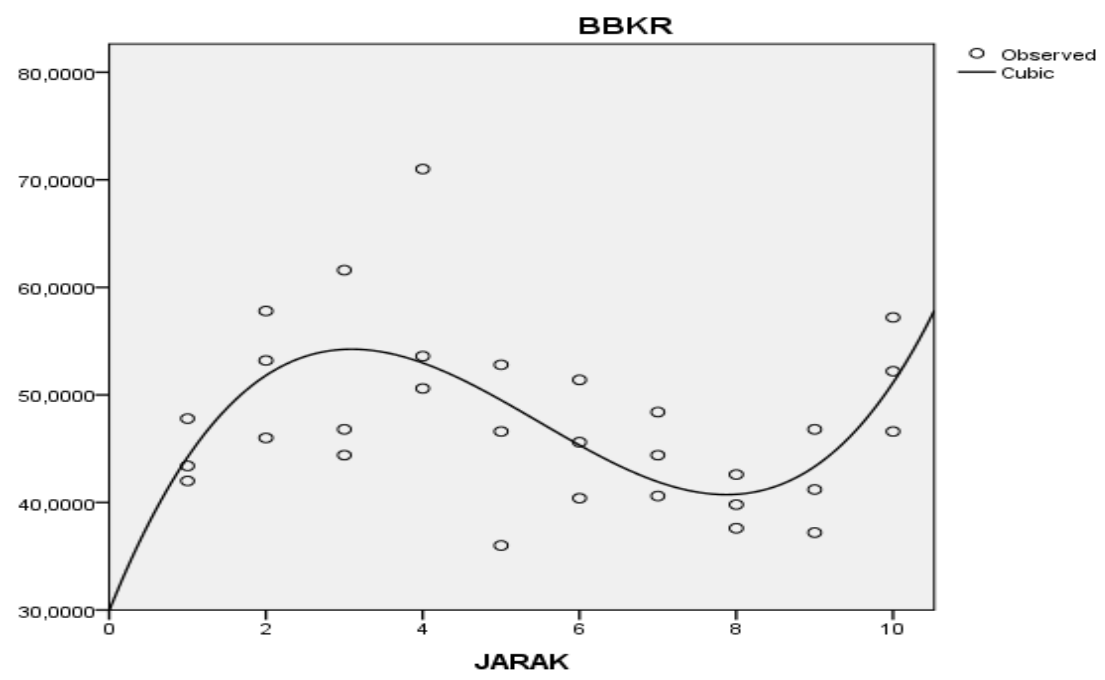

Grafik 4. Hubungan antara berat brangkasan kering per rumpun dengan jarak

Tabel 10. Model Summary and Parameter Estimates

Dependent Variable: GKP

\begin{tabular}{|l|r|c|c|c|c|c|c|c|c|}
\hline \multirow{2}{*}{$\mathrm{n}$} \\
\cline { 2 - 10 } & $\begin{array}{c}\text { Equatio } \\
\text { Square }\end{array}$ & $\mathrm{F}$ & $\mathrm{df1}$ & $\mathrm{df2}$ & Sig. & Constant & b1 & b2 & b3 \\
\hline Cubic &, 268 & 3,172 & 3 & 26 &, 041 & 577,567 & 39,976 & $\begin{array}{r}-13,055 \\
\hline\end{array}$ & 1,050 \\
\hline
\end{tabular}

The independent variable is JARAK.

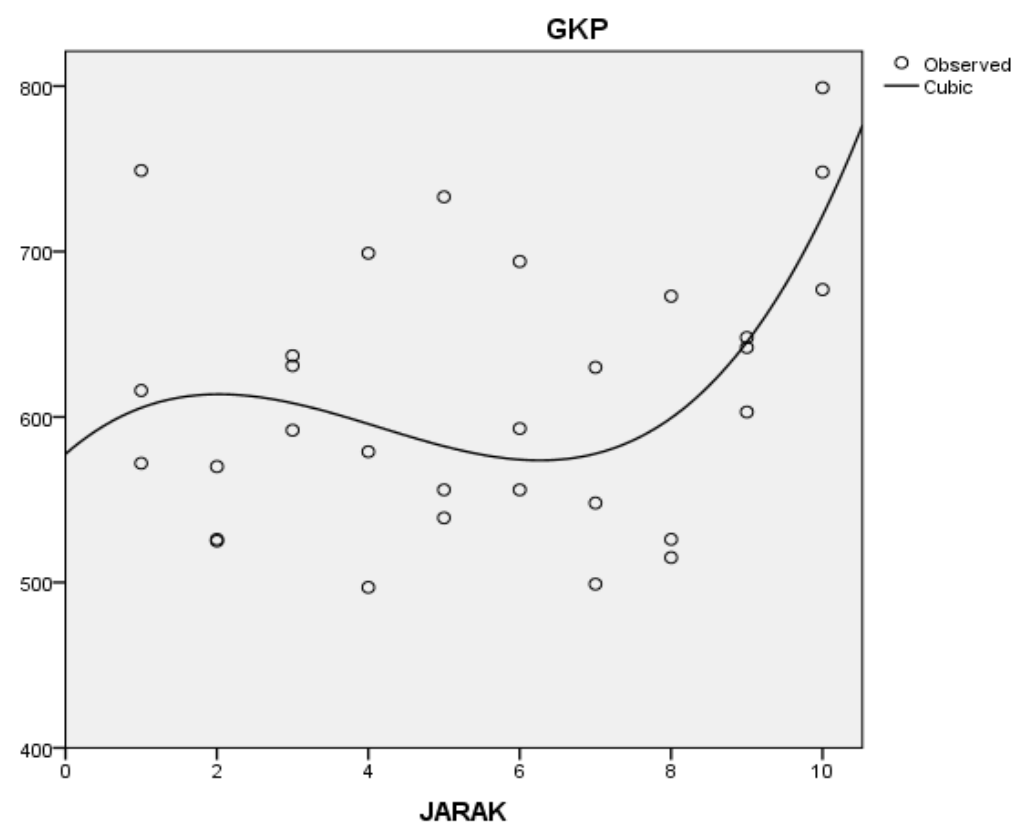

Grafik 5. Hubungan antara berat gabah kering per petak dengan jarak

Tabel 11. Model Summary and Parameter Estimates

Dependent Variable: GKR

Equation Model Summary

Parameter Estimates 
Agrisaintifika

Jurnal Ilmu-Ilmu Pertanian Vol. 5, No. 1, 2021

Rahayu, et al. 2021

\begin{tabular}{|c|c|c|c|c|c|c|c|c|c|}
\hline & $\begin{array}{c}\mathrm{R} \\
\text { Square } \\
\end{array}$ & $\mathrm{F}$ & $\mathrm{df1}$ & df2 & Sig. & Constant & $\mathrm{b} 1$ & b2 & b3 \\
\hline Cubic & ,215 & 2,371 & 3 & 26 & 094 & 42,293 & 1,469 &,- 692 & 055 \\
\hline
\end{tabular}

The independent variable is JARAK.

Tabel 12. Model Summary and Parameter Estimates

Dependent Variable: B1000

\begin{tabular}{|l|r|c|r|r|r|r|r|r|l|}
\hline \multirow{2}{*}{$\begin{array}{l}\text { Equatio } \\
n\end{array}$} & \multicolumn{4}{|c|}{ Model Summary } & \multicolumn{4}{|c|}{ Parameter Estimates } \\
\hline Cubic & R Square & F & df1 & df2 & Sig. & Constant & b1 & b2 & b3 \\
\hline
\end{tabular}

The independent variable is JARAK.

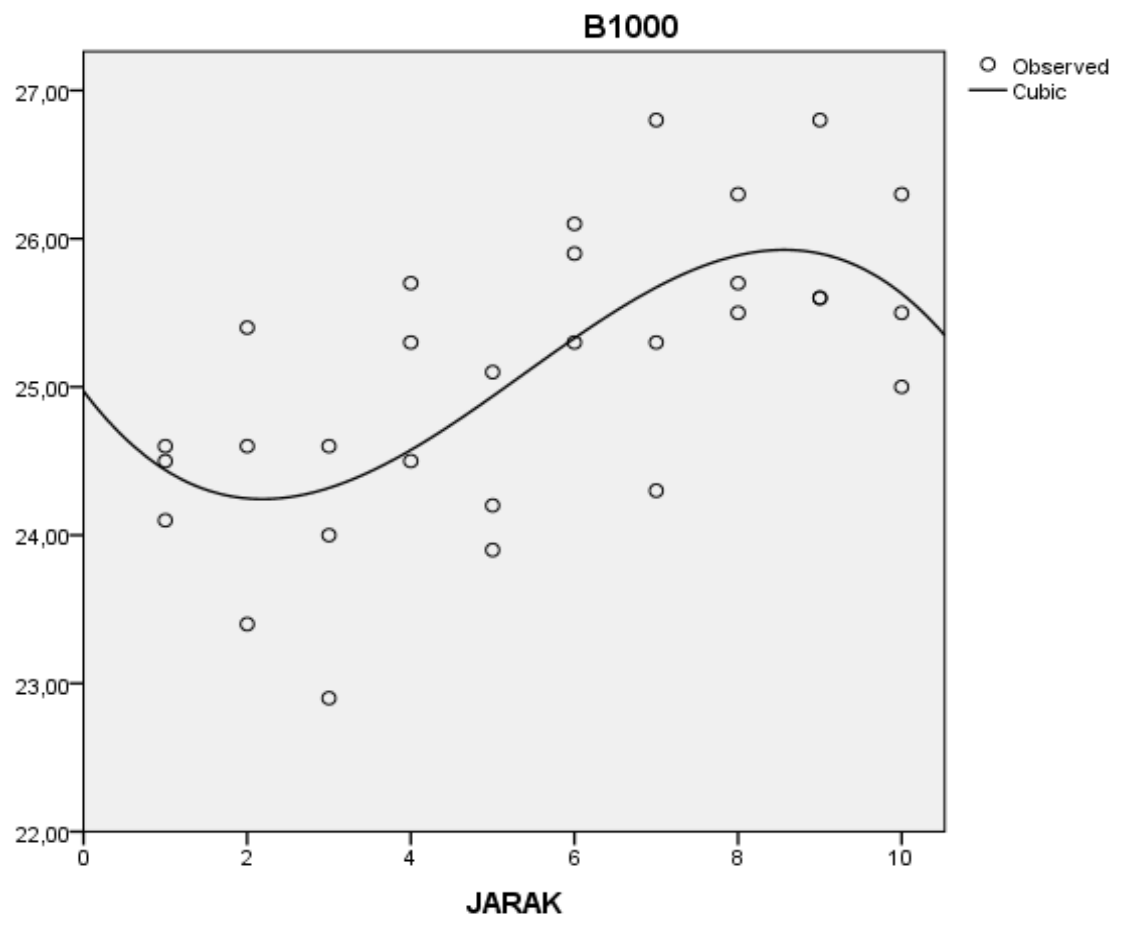

Grafik 6. Hubungan antara berat 1000 butir gabah dengan jarak 